\title{
7. National Narratives in the Representation of Nineteenth-Century Russian Monarchy
}

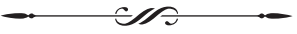

I t is a truism in the literature about Russian nationalism that a popular, democratic nationalism failed to appear in pre-revolutionary Russia. Russia diverged from the Western European model, exemplified by England, France, and Sweden, where a concept of nation evolved under the aegis of a monarchy providing continuity between pre-modern dynastic concepts of nation, and modern civic nationalism. ${ }^{1}$ One reason that this transition did not occur in Russia was that the rulers preempted national appeals and endeavored to present themselves as the expression of the will of the Russian people. Russian monarchs utilized this foundation not only to bolster their authority, but also to preclude the possibility of civic nationalism and to show that democratic institutions were alien to Russia. Russian monarchs sought to make "nationality" (narodnost') an attribute of imperial power, reflected in the past activity and identity of the monarchy—-to find in the westernized court and monarchy a common past with the Russian people.

$1 \quad$ See Alain Guéry, "L'état monarchique et la construction de la nation française," Revue de la Bibliothèque Nationale, No. 32 (Summer 1989): 6-17; Linda Colley, Britons; Forging the Nation, 1707-1837 (New Haven: Yale University Press, 1992). This corresponds to the first type of nation building in Miroslav Hroch's model: Miroslav Hroch, "From National Movement to the Fully-Formed Nation: The Nation Building Process in Europe," in Becoming National: A Reader, ed. Geoff Eley and Ronald Grigor Suny (New York: Oxford University Press, 1996), 61; On Russia see Hans Rogger, "Nationalism and the State: A Russian Dilemma," Comparative Studies in Society and History 4 (1961-1962): 253-56; Geoffrey Hosking, Russia: People and Empire, 1552-1917, xxiv, xxvi. 
To demonstrate their national credentials, Russian monarchs of the nineteenth century elaborated mythical narratives that demonstrated their bond with the Russian people. Such narratives show the ancient character of nations, common origins evolving from the past. They evoke what Etienne Balabar called a "fictive ethnicity which makes it possible for the expression of a preexisting unity to be seen in the state, and continually to measure the state against its "historic mission" in the service of the nation, and, as a consequence to idealize politics." In Russia, the mythical "idealization of politics" first took the form of an effort to identify the Petrine heritage-the westernized Russian monarchy and multinational empire-with nationality, narodnost', the term that gained currency and resonance in the first decades of the nineteenth century. The word narodnost' seems to have been first used by the poet Petr Viazemskii as a translation of the French nationalité in 1819. (Nationalité first appeared in a French dictionary in 1835). It denoted a distinctive native character or identity, but what that identity was and where it was to be found remained unclear. Whether nationality was located in a national literature, language, customs, institutions, people, or history, or some combination of the preceding, was the question intellectuals debated during successive decades. In any event, the search for a distinctive characteristic began under the influence of the French revolution and German idealistic philosophy, whether or not the word narodnost' was used. ${ }^{3}$

Russian monarchy sought to appropriate nationality for itself, denying a separate existence to the people, and trying to square the circle, to show that the westernized absolute monarchy was native in origin and spirit. ${ }^{4}$ Here I argue that this appropriation of the idea of nation assumed two quite different symbolic forms in the nineteenth century-the doctrine of official

$2 \quad$ Etienne Balabar, "The Nation Form: History and Ideology," in Becoming National: $A$ Reader, ed. Eley and Suny, 133, 140, 143-44.

3 On the question of nationality see Nathaniel Knight, "Ethnicity, Nationality, and the Masses: Narodnost' and Modernity in Imperial Russia," in Russian Modernity: Politics, Knowledge, Practices, ed. David L. Hoffman and Yanni Kotsonis (Houndsmills: MacMillan, 2000), 41-64.

4 This corresponds to the type of national myths imposed by authoritarian states, rather than those worked out through open processes of discussion. David Miller observes that the distortion of the truth in such cases may be blatant, particularly when it touches on the legitimacy of the ruler. David Miller, On Nationality (Oxford: Clarendon Press, 1995), 39. 
nationality, which defined the relations between tsar and people during the reigns of Nicholas I and Alexander II, and what I call the national myth, which was propagated during the reigns of Alexander III and Nicholas II. This formulation diverges from a widespread view that Alexander III's nationalism was merely a revival Nicholas I's. It represented, I contend, not only a different conception of the relationship between the monarch and Russian people, but a new conception of the state that played a crucial role in shaping the policies of the autocracy in the early twentieth century.

\section{Official Nationality}

Nicholas I, following the pattern of his forebears, took on a concept prevalent in the West and incorporated it into imperial mythology. The word "nationality" suggested an idea or spirit distinctive to a people; Nicholas I and his advisors identified this spirit with the westernized Russian monarchy and its past. The central themes of official nationality were expressed in the manifesto announcing the sentencing of the Decembrists issued on July 13, 1826. The Decembrists' design to introduce western constitutional institutions was alien to the Russian people. "Neither in the characteristics nor the ways of the Russian is this design to be found.... The heart of Russia was and will be impervious to it." The manifesto went on, "In a state where love for monarchs and devotion to the throne are based on the native characteristics of the people, where there are laws of the fatherland and firmness in administration, all efforts of the evil-intentioned will be in vain and insane." 5 The failure of the Decembrist uprising was itself proof of the love of the people for the monarchy and its national character, which set Russia apart from European states that had come to rely on representative institutions.

The establishment of political authority was most successful in Russia because of the Russian people's love for those who had come from outside, or appeared to come from outside, to govern them. The Russian people set the model of obedience and loyalty for the other nationalities of the empire, who also accepted subordination to a multinational elite, sharing the western culture of the Petersburg court. The monarchy demonstrated the historic devotion of the Russian people to their conquerors and rulers, in ceremony, history, and church architecture. The first ceremonial demonstration took

$5 \quad$ Shil'der, Imperator Nikolai Pervyi, 1: 704-06.

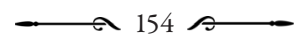


place a few months after that manifesto in the summer of 1826. After the coronation service in the Assumption Cathedral, Nicholas I made the traditional procession in full regalia stopping first at the Archangel, then the Annunciation Cathedrals. Then he ascended the Red Staircase before the Palace of Facets, turned to the crowd, and bowed three times, to their thunderous Hoorahs! The bow was an initial ceremony of recognition between the emperor and the Russian people, expressing an unspoken bond of devotion. It was a true "invented tradition," which was repeated on future ceremonial visits of the emperors to Moscow and at all future coronations. Later in the century, the triple bow came to be hallowed as an "ancient tradition" distinctive to Russia, expressing the popular character of the monarchy. ${ }^{6}$

Historical narratives now incorporated the Russian people into the dominant Petrine myth, giving the monarchy a patina of democracy by showing it to be the choice of the nation. The founding legend for the myth was the summoning of Viking princes in 862 by the people of Novgorod with the words "Our land is great and rich, but there is no order in it. Come to rule and reign over us." Nicholas Karamzin's popular History of the Russian State (1818-1829) described this as "an astonishing and nearly unparalleled case in the chronicles.... Everywhere the sword of the powerful or the cunning of the ambitious introduced absolute monarchy [samovlastie] in Russia it was confirmed by the general agreement with the citizens... The Slavs voluntarily destroy their ancient popular government and demand sovereigns from the Varangians."7

The historian Mikhail Pogodin asserted that the summoning of the Varangians revealed the paradigm of the historical development of Russia and the political order exemplified by Nicholaean autocracy. In a lecture delivered in 1832 in the presence of the Assistant Minister of Education, Sergei Uvarov, Pogodin declared, "The Varangians came to us, but voluntarily chosen, at least from the start, not like Western victors and conquerors-the first essential distinction in the kernel, the seed of the Russian State." 7 The Russian people had invited their rulers, had obeyed and loved them; autocracy had national roots. The acceptance and worship of the supreme foreign ruler had become

$6 \quad$ See Scenarios of Power, 1: 290-92.

7 Ol'ga Maiorova, “Bessmertnyi Riurik: Prazdnovanie 'Tysiacheletiia Rossii’ v 1862," Novoe literaturnoe obozrenie 43, No. 3 (2000):137.

8 M. P. Pogodin, Istoriko-kriticheskie otryvki (Moscow: A. Semen, 1846), 6-8. 
the distinguishing mark of the Russian people. The invitation was enshrined as the official version of the foundation of the Russian state. In 1851, the first volume of Sergei Soloviev's History of Russia advanced the argument that the invitation took place in 852, rather than 862, and provoked angry responses from Pogodin, N. M. Ustrialov, and others. Pogodin declared Soloviev's contention a blasphemy against one of the "sacred dates" of Russian history. In 1852, Nicholas I issued an order to the Minister of Education insisting that higher educational institutions preserve the traditional date of $862 .{ }^{9}$

The ideological formulation of these themes was the work of the Minister of Education, Sergei Uvarov, who coined the slogan, "orthodoxy, autocracy, nationality." pravoslavie, samoderzhavie, narodnost'. Uvarov advanced eighteenth-century utilitarian justifications of autocracy as the institution that had created and saved the Russian state. He did not mention divine sanction; autocracy was "the necessary condition of the existence of the empire." Orthodoxy was presented not as a revealed truth, but as the "guarantee of social and family happiness." The Russian nation was defined not as an ethnic entity, but by the utter devotion of the Russian people to their rulers, which set them apart from western peoples, seduced by liberal ideas. ${ }^{10}$ The principles of Uvarov's slogan were proclaimed and defended by a number of official writers, contributing to such state-subsidized journals as Severnaia Pchela and Moskvitianin and reflected the views of much of the educated public at the time. ${ }^{11}$

The subtext of the new version of the Petrine myth was that the institutions of the Russian state had been consecrated by its history: they were not to be judged by western ideas or the experience of western states. The history followed Karamzin's linear pattern, the passing of the tradition of autocracy from reign to reign, its culmination in the existing Russian state. The official nationality doctrine preserved and enhanced the Petrine identification of the emperor with the state. Mikhail Cherniavsky wrote that Peter's governmental institutions all were "executive extensions of Peter's personal will." 12 Much the

9 Maiorova, “Bessmertnyi Riurik," 137-40.

10 On the idealistic and utilitarian grounds of Uvarov's slogan see Andrei Zorin, "Ideologiia 'Pravoslaviia-Samoderzhaviia-Narodnosti': Opyt rekonstruktsii," Novoe literaturnoe obozrenie 26 (1996): 86-87, 92-101.

11 Nicholas Riasanovsky, Nicholas I and Official Nationality in Russia, 1825-1855 (Berkeley: University of California Press, 1959), passim.

12 Michael Cherniavsky, Tsar and People, 86. 
same can be said for the institutions of Nicholas's state. Although the Russian administration had attained massive dimensions by the end of his reign, Nicholas regarded the state as inseparable from his own personal authority. He took care to watch over his officials as closely as possible, either through the function of nadzor-administrative supervision - or through the Third Section of His Chancellery, which served, among other functions, as an organ of personal surveillance over the administration. Nicholas's person was omnipresent, and officials regarded him as the incarnation of the state. "He gives meaning and color to everything," Baron Modest Korf, a State Secretary of Nicholas, wrote. "All the radii of the many sided public activity converge on him." The imperial court in Nicholas's reign served as a display of the unity of the highest officials of the administration with the emperor and other members of the imperial family. ${ }^{13}$

Nicholas remained fully German in manner, temperament, and dress, and made known his admiration for Frederick the Great and Prussian monarchy. At the same time, he openly displayed his predilection for Russian culture and history. This took many forms: for example-preservation of artifacts of the Russian past, encouraging a national style in church architecture and Russian music, arranging ceremonial visits to Moscow. It was made clear that these were not mere instances of personal taste, but visual statements of the monarchy's identity and past. A new style in church architecture gave visual expression to Nicholas's conception of Russia's national past. Constantine Thon created an official national style, which in 1841 was established by decree. Breaking from the eighteenth-century classical models, Thon designed five-cupola churches on the model of the Vladimir and Moscow Assumption Cathedrals. His Moscow-Byzantine style is exemplified by the massive Christ the Redeemer Cathedral in Moscow, which has recently been rebuilt at its original site in the center of Moscow. The Cathedral identifies Russian Orthodoxy with the Byzantine imperial tradition, stating its distance from the Western monarchical tradition, which had proved weak and decadent. NeoByzantine decorative elements were grafted onto a massive western neo-classical structure, creating a fusion of Russian and Western motifs characteristic of the eclectic spirit of Nicholaean culture. ${ }^{14}$ (See Article 8, Figure 1).

13 M. A. Korf, “Iz zapisok,” Russkaia Starina 98 (1899): 373.

14 E. A. Borisova, Russkaia arkhitektura, 106-09; E. Kirichenko, Khram Khrista Spasitelia v Moskve (Moscow: Planeta, 1997), 61-63. 
Nicholas demonstrated the monarchy's attachment to the traditions of pre-Petrine Russia at ceremonial appearances in the Moscow Kremlin, where he repeated the triple bow he had performed in 1826. These trips assumed especial importance after the revolution of 1848 , when ancient Rus' signified the religious national faith that preserved Russia from the dissension and upheavals that had afflicted the West. These displays of national affiliation confirmed rather than contradicted the authority of Nicholas's westernized elite. He called upon the traditions of ancient Moscow but without wishing to revive them.

Some of the more nationally inclined writers, like Pogodin and Stepan Shevyrev, on the other hand saw the emperor's presence as a sign of a return to Muscovite culture. The difference between their image of a national monarchy and the emperor's became clear during a visit to Moscow in 1849 to dedicate Thon's New Kremlin Palace. Pogodin wrote that Nicholas assumed a different persona when he left the setting of the palace. "Are the Russian Tsar and the European Emperor two persons? No, they are one! From the Vladimir Hall [of the new Kremlin Palace] it is only a few steps to the Hall of Facets and the Red Staircase. Once [Nicholas] opens the door to the people, or even opens the window of Tsar Alexei Mikhailovich, all of Moscow, and with her all of Russia will see and hear him and answer, 'The European Emperor is again the Russian Tsar!'” Pogodin's article, however, did not pass the censors. ${ }^{15}$

The efforts of the Slavophiles to recapture their conception of early Russian culture evoked a sharp response. When Alexei Khomiakov, Constantine Aksakov, and several other Slavophiles ventured to appear at court in beards and what they believed was the Russian clothing of early Russia, a swift rebuke came down from the Ministry of Interior. A circular of the Ministry of Interior to provincial marshals of the nobility, announced that "The tsar is displeased that Russian noblemen wear beards. Because for some time news has been received from all provinces that the number of beards has greatly increased." It went on to explain that in the west, beards were "a sign of a certain type of ideas. We do not have this here." The tsar, it concluded, "considers that beards will interfere with the nobleman's elective service." 16 In Nicholas's frame of mind, beards signified not Russians but Jews and radicals. The official view

15 Nikolai Barsukov, Zhizn' i trudy M. P. Pogodina (St. Petersburg: M. M. Stasiulevich, 1898) 10:234-35, 238.

16 Ibid., 10: 250-51. 
identified the nation with the ruling western elite, and the suggestion that there was another, contradictory measure of the nation in the peasantry or the past intimated rebellion. Nicholas's shows of national spirit were meant to preserve, not to narrow the distance between the autocratic-noble elite and the ruled: to dramatize obedience as a spiritual quality of the nation. Authenticity, truth, and other versions of the national past jeopardized the monologic universe of the imperial myth. The beard symbolized a coming together of elite and people in a national culture whose features were not defined by the autocratic power. ${ }^{17}$

The official nationality narrative also provided the grounding for a dynamic view of the monarch as the ruler of a reformed state leading a mission of building a dynamic and powerful Russian empire. Such figures as N. N. Murav'ev, A. P. Balasoglo, N. I. Nadezhdin, and other members of the Russian Geographical Society envisioned a revitalized Russian empire that would represent the Russian nation. ${ }^{18}$ The presumption of the devotion of the Russian people to a monarch who embodied the state and empire underlay the rationale for the Great Reforms. The steps taken on behalf of the people by the monarchical state justified the love of the people to their sovereign. Reform had been a goal of Nicholas's enlightened despotism, though fear of disruption deterred all but a few efforts to introduce change. Alexander II's scenario adapted the ideas and images of official nationality to a program of reform. He appeared as the humane European monarch, conferring benefactions on a grateful and devoted people-the emancipation of the serfs, the establishment of reformed courts and organs of local self-government. The Great Reforms were presented as expressions of the love uniting sovereign and people, distinctive to Russia, which would enable Russia to reap the benefits

17 On the meanings imputed to the wearing of beards among the Slavophiles, and the Slavophiles' responses, see N. N. Mazur, "Delo o borode: Iz arkhiva Khomiakova: pis'mo o zapreshchenii nosit' borodu i russkoe plat'e," Novoe Literaturnoe Obozrenie, No. 6 (1993-1994): 127-38.

18 Mark Bassin, Imperial Visions: Nationalist Imagination and Geographical Expansion in the Russian Far East, 1840-1865 (Cambridge: Cambridge University Press, 1999), 12-13, 94-101; Nathaniel Knight, "Narodnost' and Modernity in Imperial Russia," 48-50; Nathaniel Knight, "Science, Empire, and Nationality: Ethnography in the Russian Geographic Society, 1844-1855," in Imperial Russia: New Histories for the Empire, ed. Jane Burbank and David L. Ransel (Bloomington: Indiana University Press 1998), 108-42. 
of increased freedom and social development while avoiding the political upheavals of the West.

Following the promulgation of the emancipation manifesto in February 1861, demonstrations of gratitude and approval by the people showed the popular grounding of monarchical power fundamental to official-nationality thinking. The tsar remained the supreme westernized figure of godlike elegance, distant from his people and bestowing the benefits of progress and civilization upon them. Popular prints (lubki) issued in the era of emancipation present Alexander II standing above peasants and workers on their knees in prayer, displaying gratitude and adoration to the emperor, a figure from a higher realm. ${ }^{19}$ The anniversary of the Millenium of Russia in Novgorod in 1862 celebrated the emblematic act of rapport between ruled and their rulers in 862. Alexander addressed the Novgorod nobility calling the celebration "a new sign of the indestructible bond of all the estates of the Russian land with the government with one goal, the happiness and well being of our dear fatherland." 20

\section{The National Myth}

The great divide in the history of the representation of the Russian emperor in the nineteenth century occurred not with the Crimean War and death of Nicholas I, but with the assassination of Alexander II in 1881. The assassination dealt the final blow to the Petrine myth, the notion that Russian monarchy embodied the ideal of the European absolute state, but surpassed its models in power, majesty, and virtue. If the official nationality doctrine accommodated the concept of nation to the Petrine myth, Alexander III's scenario presented the emperor as the hero of a national myth that emphasized his ethnic character as the most Russian of Russians, who stood apart from the westernized Russian state.

The images and themes of the myth took form in the 1860s and 1870 s among the members of the so-called "Russian party," which consisted of officials and journalists, disaffected one way or another from the policies of Alexander II, such as Constantine Pobedonostsev, Mikhail Katkov, and Vladimir Meshcherskii. Their conceptions of the nation were vague and

19 See Scenarios of Power, 2: 71-75.

20 Tatishchev, Imperator Aleksandr II, 1: 404. 
diverse, but they all opposed what they perceived as irresolute domestic foreign policies and a want of characteristically Russian traits. None of their views corresponded to the notion of civic nation, which they considered alien to Russia's culture and past.

The new national myth was elaborated in the manifesto of April 29, 1881. The manifesto, drafted by Pobedonostsev, brought to an end the discussions of governmental reform that had continued under Loris-Melikov's direction in the weeks after the assassination. ${ }^{21}$ The manifesto made the autocratic, unlimited power of the tsar appear as both a divinely ordained obligation and the mandate of the Russian people. Revising the initial text, Pobedonostsev changed the words "the burden of supreme rule," "bremia verkhovnogo pravlenia" to "the holy duty of Autocratic rule," "sviashchennyi dolg samoderzhavnogo pravleniia." 22 This gave divine sanction to the tsar's absolute power-not only to the sources of imperial power, but also to the way it was exercised.

The people displayed their devotion to the monarchy not as they had under Alexander II, in demonstrations of gratitude for benefactions bestowed on them. Rather, they showed that the forms of national consent were religious, demonstrated through the institutions of the church, in prayer: "the fervent prayers of a pious people known throughout the entire world for their love and devotion to their sovereigns." These prayers brought divine blessing on their sovereign.

The manifesto replaced the early eighteenth century with a new founding period of Russian monarchy. Pobedonostsev wrote not of the Russian state or empire, but the "Russian land" "zemlia russkaia." The "Russian land" evoked a Slavophile picture of the unity of all estates in Russia, a single people, living in harmony with their tsar. The people in this way became inseparable from an image of an original, undifferentiated abstraction of the land, uncorrupted by the institutions of the Russian state. The Russian land now had been disgraced by vile sedition, but "hereditary tsarist power," continued to enjoy the love of its subjects, and this power "in unbreakable ... union with Our land" had survived such troubles_smuty —in the past. The historical paradigm now shifts from the legend of the calling of the Varangians to a picture of an

$21 \quad$ PSZ, Sobranie 3, no. 118, April 29, 1881.

22 O. Maiorova, "Mitropolit Moskovskii Filaret v obshchestvennom soznanii kontsa XIX veka,” Lotmanovskii Sbornik, 2 (Moscow: O.G.I., 1997), 617. 
idealized Muscovite state. The elevation and glorification of the monarch now took place by claiming to inhabit another time frame, when the tsar was in contact with the nation. The distance between the ruler and educated society was the distance between him and the manifestations of the fallen present that encumbered his power. After Alexander III's death in 1894, Moskovskie Vedomosti described him as the initiator of a new period in Russian history, "the Russian period"; he was the "great moral gatherer of Russian land," placing him among the princes of Moscow. He had restored "Russian autocracy," which had been realized in Muscovy when the idea of autocracy received from Byzantium had gained its distinctively Russian character. If the national myth sought to divest Russian autocracy of its western trappings, it also announced the separation from its Byzantine origins, which had been emphasized under Nicholas I. ${ }^{23}$

The synchronic mode characteristic of late nineteenth-century nationalist and racial ideologies replaces the linear development of the Petrine myth. The synchronic mode was profoundly anti-traditional, for it diminished the heritage of the eighteenth and nineteenth centuries and delegitimized the legalistic bureaucracy, the intelligentsia, and the dynamic of reform that had reached its culmination in the previous reign. It looked back to a timeless heritage, untouched by historical change. The Russian emperor might live in Western-style palaces, consort with Western royalty, and share European culture, but these superficial overlays concealed a national substratum (ustoi) that could be recovered through a restoration of the earlier political and spiritual order.

The image of tsar and people expressed the close cultural and even ethnic affinity that Alexander III claimed with his subjects. Again, the persona of the emperor was displayed early in his reign, and in public ceremonial form. ${ }^{24}$ Alexander III was presented as "Russian tsar" in the first months of his reign. Despite his parentage, culture, and frequent trips to Denmark, he was elevated as the embodiment of the nation. Alexander's great size, his surly and uncouth manner, his impatience with the niceties of society made it possible to present him as one alien to the educated elite, whose character was close to the Russian narod. Most obviously, he was the first Russian monarch since the seventeenth

23 S. Petrovskii, ed., Pamiati Imperatora Aleksandra III (Moscow: S. Petrovskii, 1894), $175,286$.

24 See Scenarios of Power, 2: 204-06. 
century to wear a beard. While wearing beards had become fashionable among the upper classes by the 1880 s, a large red beard on the face of Russian monarch was a statement of association with pre-Petrine Russia. The image of his massive figure in a Russian hat and jackboots was the antithesis of the former sleek look of the guards' regiments. It evoked the image of the bogatyr', the burly epic heroes of early Russia, a reaffirmation of state power, coming from within, from Russia itself.

The change was displayed in a new look given to the military. Shortly after his accession, Alexander issued permission, which was taken as an order for guards' officers to wear beards. (Guardsmen previously had been allowed only a two finger-widths unshaven strip on their chins.) Soon nearly all guards' officers appeared with beards, though some thought that this gave them the look of peasants (omuzhichanie). New Russian-style uniforms were introduced, including the high Russian boots and fur hats. At the same time, the guards, the paragon of Petrine westernization, were surrounded by religious symbols of old Russia. For the first time, banners of the regiments were emblazoned with icons of their patron saints. Eightpointed Orthodox crosses appeared at the top of the flagstaffs. ${ }^{25}$ V. I. Gurko later wrote that this fusion of "military and religious ceremonies" produced a feeling of elation, as the monarch became the symbol of the people's might. Such ceremonies, he wrote, were a distinguishing feature of the Russian court, which reflected the spirit of "the ancient Muscovite empire' permeated with religious and secular powers which complemented each other and formed one whole." 26

The representations of the monarchy now sought to detach the image of imperial Russia from St. Petersburg and locate it in a new image of Moscow. Symbolic Moscow did not encompass modern Moscow, the city of factories, the liberal intelligentsia and often fractious nobility. It was the Moscow of the Kremlin and Red Square, recalling an idealized past of spiritual unity between tsar and people and a devotion to the autocratic ruler unsullied by foreign doubts. In the summer of 1881, less than six months after his accession, Alexander unexpectedly announced his desire to travel to Moscow. In the Kremlin, he declared, "Moscow has always served as an example for all of Russia. I hope this

25 Ibid., 2, 244-56.

26 V.I. Gurko, Features and Figures of the Russian Past (Stanford: Stanford University Press, 1939), 340. 
will be true in the future. Moscow has attested and now attests that in Russia, Tsar and people compose one, concordant (edinodushnoe) strong whole." 27 Then, after a religious service, he stepped out onto the Red Staircase to perform the triple bow and to receive the acclaim of the crowd. (See Article 8, Figure 1).

Alexander's coronation in 1883 confirmed his belief that he was returning Russia to its Muscovite roots. In a letter to the empress on its first anniversary, he described the coronation as a "great event for us. And it proved to a surprised and morally corrupt Europe that Russia is still the same holy, orthodox Russia as it was under the Muscovite Tsars and, if God permits, as it will remain forever." 28 The new prominence of the Orthodox Church showed the persistence of "holy, orthodox Russia." Under Pobedonostsev's direction, the church supplanted the state as the principal national institution of the monarchy. The Holy Synod encouraged the spread of religious literature, the building of church schools, and the expansion of church construction. It permitted the spread of pastoral movements among the secular clergy. The spirit of Russia's religious past was recalled in great religious commemorations staged to show the autocracy's debt to Orthodoxy and the national following commanded by the church. ${ }^{29}$

A new official national style of church architecture demonstrated a return to an original Russian spirit. The government gave proof of the vitality of early Russia by building Orthodox churches in Muscovite style. Alexander himself wanted the Cathedral of the Resurrection to be built on the site of his father's assassination in "the Russian style." Russian style meant for him not the Thon, Moscow-Byzantine style of the Redeemer Cathedral but "the style of the times of Moscow tsars of the seventeenth century." By this Alexander meant the flamboyant forms of Vasilii the Blessed on Moscow's Red Square. The external

27 Vsemirnaia Illiustratsiia no. 656 (1881): 102.

28 GARF, 642-1-709, 24-25. Letter of May 16, 1884.

29 Seventeen jubilee celebrations marked great religious events of Russia's past during Alexander's reign. The five-hundredth anniversary of the Tikhvin Mother-ofGod and the centenary of the death of Tikhon Zadonskii took place in 1883. The millennium of Cyril and Methodius followed in 1885, the nine-hundredth anniversary of the baptism of Rus' in 1888, the fiftieth anniversary of the union with the Uniates of the Northwestern region and the five-hundredth anniversary of the death of Sergei of Radonezh in 1892. See A. Iu. Polunov, Pod vlast'iu ober-prokurora: gosudarstvo i tserkov'v epokhu Aleksandra III (Moscow: AIR0-XX, 1996); Scenarios of Power, 2: 239-44. 
devices-tent forms, the tracery, kokoshniki, and shirinki-borrowed from a great number of seventeenth century churches in the Moscow-Iaroslavl style-are in great contrast with the more reserved and symmetrical forms of the Redeemer Cathedral. Although the Resurrection Cathedral, usually called "the Savior on the Blood," was not consecrated until 1907, it provided the model for church design in the official Russian style after $1881 .{ }^{30}$ (See Article 8 Figure 2). A report Pobedonostsev wrote as Chief Procurator of the Synod in the 1890s asserted that Alexander himself reviewed projects for churches and "willingly approved those projects that reproduced the ancient tradition of Russian churches." 31

The evocation of Muscovy, couched in Slavophile rhetoric and images, distanced the person of the monarch not only from westernized educated society, but from the institutions of the absolute state, encumbered by forms of European legality and institutional autonomy. For Alexander III and his advisors, the monarchy could regain its lost authority only by a signal rejection of more recent governing traditions, which had enervated and constrained the exercise of autocratic power. The Russian tsar now embodied not the existing state, but the nation, existing from distant times, and it was his personal authority, wielded with diminished regard for legal and bureaucratic formalities, that could bring about the spiritual union between tsar and people.

The seventeenth century provided a paradigm for a state power of a different type, a government responsive to the monarch's will that could reunite an administration divided by considerations of legality and institutional autonomy. The manifesto of April 29, 1881 associated the origins of the Russian nation with the restoration of monarchical authority after the breakdown of the Time of Troubles. The "Voice of God" ("Glas Bozhii") had summoned the tsar "to turn vigorously to the task of Ruling, with hope in Divine Providence." He would rule, he promised, "with faith in the force and truth of Autocratic power, which we have been summoned to confirm and preserve for the people's welfare from all encroachments." The word "vigorously," (bodro) bespoke an assertion of energetic, ruthless authority, inspired by the faith in God and the prayers of the people.

$30 \quad$ Scenarios of Power, 2: 244-56

31 Polunov, Pod vlast'iu ober-prokurora, 76. 
Bodro became a common term in the rhetoric of conservative periodicals in the call for reaffirmation of autocratic power. Alexander's stern and brooding mien, his brusqueness and crudity, presented him as a model of that era, an incarnation of unyielding will and determination. He sought to restore early Russian autocracy by making the spheres of government directly responsive to his wishes-police, finances, and foreign policy. These spheres would be directed by men completely loyal to him, those he regarded as truly Russian. The elite of Russian monarchy now narrowed to those sharing the tsar's national vision, who were endowed with energy and shared Alexander's arrogance of untrammeled power. Together, he and his servitors created an image of strength that exalted Russian monarchy when the empire's international standing had declined, its finances were in disorder, and many high officials cherished a sense of legality that challenged the totality of autocratic rule.

The anti-bureaucratic rhetoric that the Slavophiles had used to denounce the entire state administration now served to discredit those parts of the government resistant to the personal power of the monarch, especially the State Council and the court system. The contrast with Nicholas I's Official Nationality, which validated the perfection and reinforcement of the existing administrative system, is clear. An article in Moskovskie Vedomosti upon Alexander III's death remarked that the official nationality under Nicholas I remained some kind of "state patriotism," "kazennyi patriotizm" and "was not embodied in living phenomena." Nicholas I "was not yet conscious with full clarity of the complete separation between Russia and Europe by type, was not conscious of the complete distinction of Russian autocracy from Western European monarchism."32

The model for Alexander III's national state was set forth in the pages of Russkii Vestnik by Mikhail Katkov's protegé, the Simbirsk landlord, Alexander Pazukhin. Pazukhin evoked a seventeenth-century Russian state based on close cooperation between nobility and bureaucracy, where noblemen served as willing executors rather than as independent citizens. For Pazukhin, the seventeenth century was a period of administrative consolidation and growing state power in Russia. The "land" zemlia comprised for him not a community of the people, as it had for the Slavophiles, but the "state ranks" (gosudarstvennye chiny). "The estate organization in the mind of the old

32 Petrovskii, ed., Pamiati Imperatora Aleksandra III, 288-89. 
Russian person was the guarantee of order and tranquility in the country." Peter was not the founder but the beneficiary of an estate system that he used to bring Russia closer to the West. ${ }^{33}$

The Slavophile picture of the seventeenth-century served to delegitimize the post-reform state with its striving for legality and autonomy. Pazukhin's writings provided a historical paradigm for counter-reforms that aimed to extend the authority of the monarch, through administrative institutions of the Ministry of Interior, to the local landed nobility, reconstituting the personal bond between the monarch and the estates that had presumably existed in seventeenth-century Russia. The national myth also provided historical grounding for the enhancement of the role of Russian religion and language in the governing of subject nationalities. It announced a break with the old model of a multinational elite - a group united by service to their sovereign, and a common domination over subject nationalities, among whom the Russian people were exemplary in their devotion and subservience. Now, the non-Russian elites could no longer be trusted. The national autocracy identified loyalty and administrative effectiveness with Russian ethnicity and Russian domination of other nationalities. In the western provinces and Poland the new myth justified policies of Russification, while in Central Asia they provided a rationale for a Russian colonial administration ruling over subject nationalities.

To be sure, few of these goals were realized during Alexander III's brief reign. Pobedonostsev's schemes to reinvigorate the clergy as agents of national consciousness foundered on his policies of central administrative control of the activities of the church. The counter-reforms were resisted and in many ways emasculated in the State Council. The Petrine state asserted itself in the persons of the liberal bureaucrats and noblemen from the reform era, who continued to oppose changes in government particularly in the State Council and the Senate. Efforts at Russification in most areas encountered practical obstacles in the local nobilities and administration and fell short of their

33 A. D. Pazukhin, "Sovremennoe sostoianie Rossii i soslovnyi vopros," Russkii Vestnik (January 1885): 41-47. Alfred Rieber has suggested that Pazhukhin's text may date from as early as 1881 . This would indicate that his rhetoric and historical imagery was rooted in Alexander's scenario as it was presented in the first years of the reign. See Merchants and Entrepreneurs in Imperial Russia (Chapel Hill, NC: University of North Carolina Press, 1982), 95n. 
original goals. In many areas, they awakened the national consciousness and stimulated opposition among the subject nationalities.

The national myth continued to define the goals and to represent the symbolic reality of autocratic Russia after Alexander's death in 1894. Nicholas II saw himself not as heroic westernized ruler, asserting his power through the Petrine state, but as exemplar of the nation, and unlike his father he did not envision a new administration or officials in the image of Pobedonostsev's ideal officials. Nicholas's distrust of governmental officials was visceral-more profound, all-encompassing, and undifferentiated than his father's. In the first years of the twentieth century, the imperial Russian state came under challenge both from a growing opposition movement demanding constitutional reform, and a no less insurgent monarch, determined to create a form of personal rule that would express his direct bonds with the Russian people, the peasants. ${ }^{34}$

Russian monarchical nationalism presented appeals to counter democratic ideologies, seeking to thwart the transition from dynastic to civic nationalism that had taken place in the West. National narratives first evoked a past that presented the westernized autocracy as the object of the Russian people's desire for strong authority imposed from above. Later, they emphasized the Russian character of the tsar, who restored strong autocratic rule based on an original unity between tsar and people that had been destroyed by western thought and culture. The image of national monarch sustained the mythical aura of the emperor. It helped preserve forms of mythical thinking that precluded any hint of dissent or politics that might mar the epic unity and silence of the myth by admitting negotiation and compromise.

Monarchical nationalism in Russia proved a potent factor impeding the rise of a democratic nationalism that might unite state and society. This became clear after the revolution of 1905 , when efforts to work within the conservative framework of the Third and Fourth Dumas encountered Nicholas II's stubborn distrust and resistance. The great historical celebrations that took place between 1909 and 1913, and especially the Tercentenary celebrations of 1913, he believed, showed that the people were devoted to him and not to elective institutions. Civic or even ethnic concepts of the unity of the Russian nation could not be reconciled with a narrative that emphasized the historical bonds of the people with the

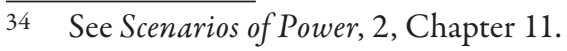


monarch. The popular, conservative Russian nationalism that began to spread through moderate society after the revolution of 1905 appeared to Nicholas II as merely another threat to the unity of tsar and people contributing to division and strife in Russian society. On the other hand, liberal thinkers and political leaders found it difficult to disengage concepts of nationality from the institution that represented a backward and oppressive order. The various groups in Russian society could find little grounds for unity on the eve of a massive war that demanded the common efforts of a united nation. 